\title{
CHANGES OF THE PALAEO-GEOGRAPHICAL CONDITIONS IN THE LAKE USMA DEPRESSSION DURING THE END OF THE LATE GLACIAL AND THE HOLOCENE
}

\section{Paleoǵeogrāfisko apstākḷu pārmaiṇas Usmas ezera ieplakās leduslaikmeta beigās un holocēnā}

\author{
Ivars Strautnieks, Elīna Deksne, Laimdota Kalniṇa, \\ Aija Cerina, Andra Štube \\ University of Latvia, Faculty of Geography and Earth Sciences \\ ivars.strautnieks@lu.Iv
}

\begin{abstract}
Lake Usma occupies the lowest part of the Late Glacial glacio-depression at the Kursa Lowland (NW Latvia), where the Venta-Usma ice-dammed lake and the Baltic Ice Lake sediments have been accumulated. Geological and geo-morphological investigations have been carried out on the largest Lake Usma islands - Moricsala and Viskūži Island as well as at Košķēni Bay. Changes in palaeo-geographic conditions in the Lake Usma depression during the Holocene are evidenced by organogenic sediments from cores in Moricsala and Viskūži Island and in the lake bottom of Košķēni Bay. The loss on ignition analysis of these sediments has been carried out with the aim to determine changes of organic, mineral and carbonate matter proportions and the relative percentage in their composition, which together with macro-remain analysis data allow to gain better understanding about the character of the palaeogeographic conditions during the lake's development,
\end{abstract}

Keywords: relief, Košķēni Bay, loss on ignition, Moricsala, Viskūži Island

\section{Introduction}

Lake Usma, is located in the N-W part of Latvia and occupies the lowest part of the Late Glacial glacio-depression at the Kursa Lowland, where the Venta-Usma icedammed lake and the Baltic Ice Lake sediments have been accumulated. The lake is $13.5 \mathrm{~km}$ long and $6.2 \mathrm{~km}$ wide, oriented towards N-E (Figure 1 - a). The shoreline of the lake, bays and peninsulas is overgrown and paludified. There are four islands in the lake - Viskūži Island, Moricsala, Lielalksnīte and Mazalksnīte. Viskūži Island is the largest lake island in Latvia with length $3.1 \mathrm{~km}$ and $1.75 \mathrm{~km}$ wide. It is a natural border between the northern and the deepest southern part of Lake Usma. The peninsula at the eastern shore of the lake, Viskūži Island, and Amjūdze Peninsula forms a transverse elevation in the middle part of Lake Usma (Figure $1-a, b$ ).

The genesis of the Lake Usma depression and its surrounding area at the end of the last glacial and the Holocene has been described in published and unpublished interpretations in the late 20th century by Quaternary researchers E. Grīnbergs (Гринбергс 1957), I. Veinbergs (Вейнбергс 1975; 1999). Of particular note, mention should be made of the investigation carried out by I. Veinbergs and I. Jakubovska (Veinbergs and Jakubovska 1999), which was based on geological, geo-morphological and palynological research. In this study it was found that the glaciolimnic clay rhythm and the thickness of the layers series were conditioned by changes in the accumulation conditions at the end of the glaciation. Information about the 
morphology of the lake depression and the islands and the fixed levels of terraces provided by the research data allows us to understand the Venta-Usma ice-dammed basin and the Baltic Ice Lake levels changes in the area of Lake Usma. Palynological analysis of organo-genic sediments was carried out for sediment sections from Moricsala, Ozolini valley, and Usma station bog in that study, however there was not given sufficient attention to the sediment composition. Recent studies include analyses of organo-genic sediments from Košķēni Bay, Moricsala and Viskūži Island (Figure 1 - a).
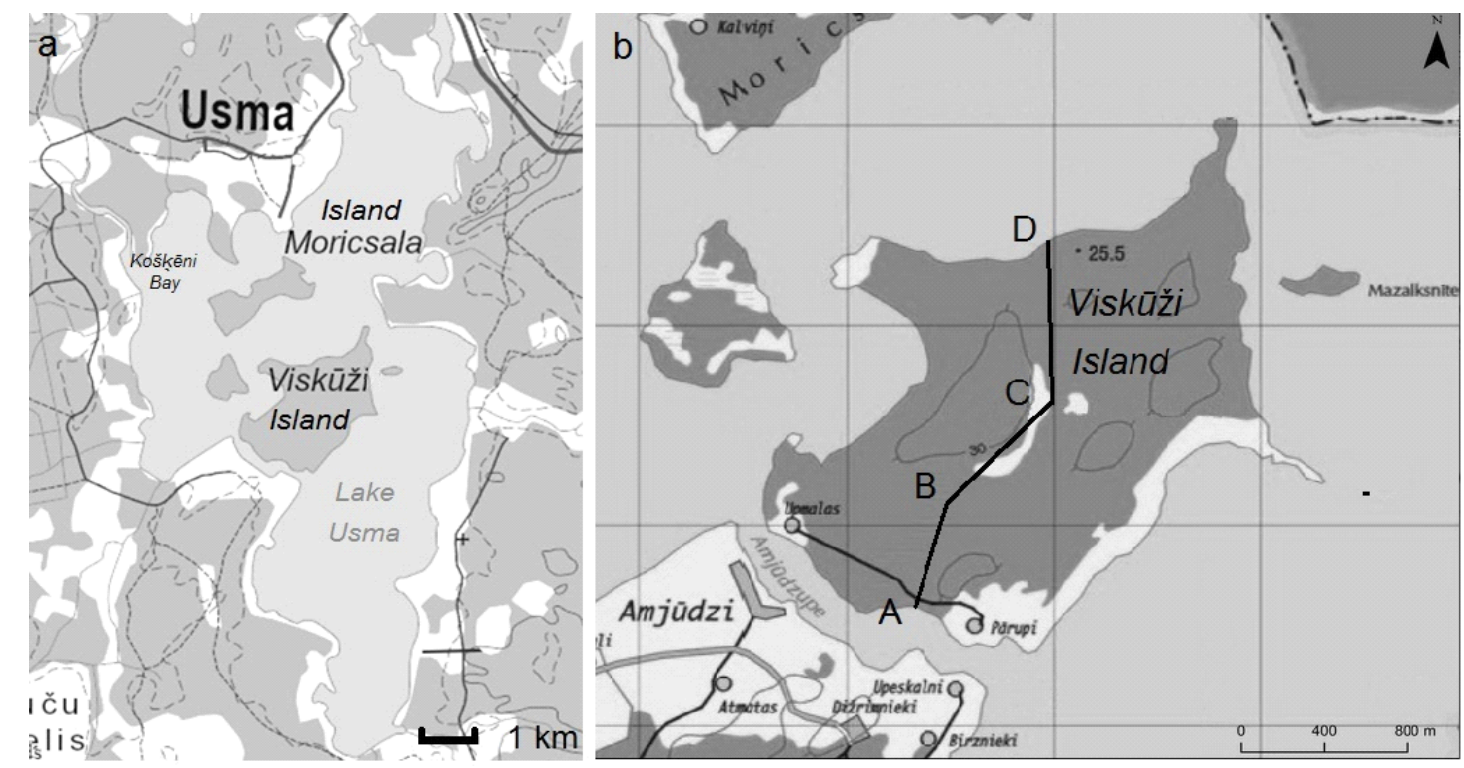

Figure 1. Location of studied sites: a) in the Lake Usma; b) Viskūži Island. Line A-B-C-D on the Viskūži Island shows the location of the geological longitudal section of the organic deposit distribution in the island valley (authors' figure using Latvian Geospatial Information Agency Map 1:100 000 (a) 1: 1:50 000 (b)).

The aim of this study is to find out the main stages of palaeo-geographic condition change during the development of Lake Usma as recorded in the sediments.

\section{Materials and Methods}

The field work for this study was carried out on Moricsala and in Košķēni Bay and in 2016 on Viskūži Island. The sediments found in the adjacent areas of Lake Usma and its islands are sufficiently representative to trace the changes of paleogeographic conditions at the end of the Pleistocene and in the Holocene by the sediment accumulations and lithological characteristics, thickness and sequences of the layers. More detailed geological and geo-morphological studies have been carried out on the two largest islands of the lake - Moricsala and Viskūži Island and in Košķēni Bay. Viskūži Island and Moricsala were formed as a result of ice meltwater basin sediment accumulation, and of the erosion of ice melting water streams and waves. 
Sediments from the Moricsala, Košķene and Viskuži Island sections have been studied by loss on ignition analysis (LOI), macro-remain analyses and sediment age dating with the AMS ${ }^{14} \mathrm{C}$ method. LOI methodology was applied for sediment analysis in order to estimate the content of organic matter, carbonates and mineral matter in the sediment composition. Analysis was carried out by heating the samples sequentially at $550^{\circ} \mathrm{C}$ for $4 \mathrm{~h}$ and at $900^{\circ} \mathrm{C}$ for $2 \mathrm{~h}$ (Heiri et al. 2001). Fluctuations in values of these sediment characteristics point to changes in sedimentation conditions.

Samples (selected terrestrial macro-remains) were prepared according to the specifications and sent to the Poznań University laboratory for dating with AMS ${ }^{14} \mathrm{C}$ method.

\section{Results and Discussion}

Results of laboratory investigations help us to better understand the paleogeographical conditions of Lake Usma. Loss on ignition analysis reveals quite unstable sedimentation conditons in the lower part of the Košķēni Bay sediments (Figure 2) in comparison with the Vizkūži Island section (Figure 3). A high proportion of carbonates in the lower part of both sites indicate favourable conditions for carbonate accumulation, which disappear upwards, before 6700 cal years BP (calibrated years before the present) in Viskūži sections and 5000 cal years BP. In the Moricsala section carbonates are found in only a very little amount (Ceringa et al. 2017).

Particularly important information is provided by the results from LOI analysis of the $11 \mathrm{~m}$ thick organogenic sediment layer on Viskūži island (Figure 4 - core Z1) supported by the AMS ${ }^{14} \mathrm{C}$ datings. The Viskūži LOI diagram shows overlying sapropel composition in the lower part of the section (Zone 1) and contains a quite high amount of mineral matter and carbonates, but from the depth $8.6 \mathrm{~m}$ upwards, these values decrease (Figure 3). In the sapropel up to a depth of $7.56 \mathrm{~m}$ there are to be found regularly abundant waterfleas (Cladocera), which are present in both the litoral and pelagic part of the lakes. In the sediment section higher up, organic matter content increases significantly and reaches $90-95 \%$. Aquatic animal remains from a depth of $7.55 \mathrm{~m}$ upwards are to be found in a small number of individual samples that indicate the disappearance of the open water surface and the accumulation of deposits started under fen conditions. There were also to be found Sphagnum and Hypnales moss leaves, bog fern leaves, Bogbean, sedge and Rannoch-rush seeds.

The main features of the morphology, relief and sediment characteristics are important criteria for palaeo-geographic development of the Lake Usma area. The geological mapping materials of Latvia in scale M 1:200 000 (1999), large-scale topographic maps and surface models of terrace created after the LGIA aerolaser scanning in 2016 data were used.

Viskūži Island is separated by a $300 \mathrm{~m}$ wide strait from the shore of Lake Usma, but a 160-200 m wide and $1.3 \mathrm{~km}$ long winding strait, separated from the island by the morphological similarity with the river, is named Amjūdzupe (Figure 1). Viskūži 
Island, together with the above-mentioned peninsulas, forms a linear elevation drawn in the direction of SW-NE, the base of which may fix one of the positions of the active ice tongue at the end of the late Visla glaciation.

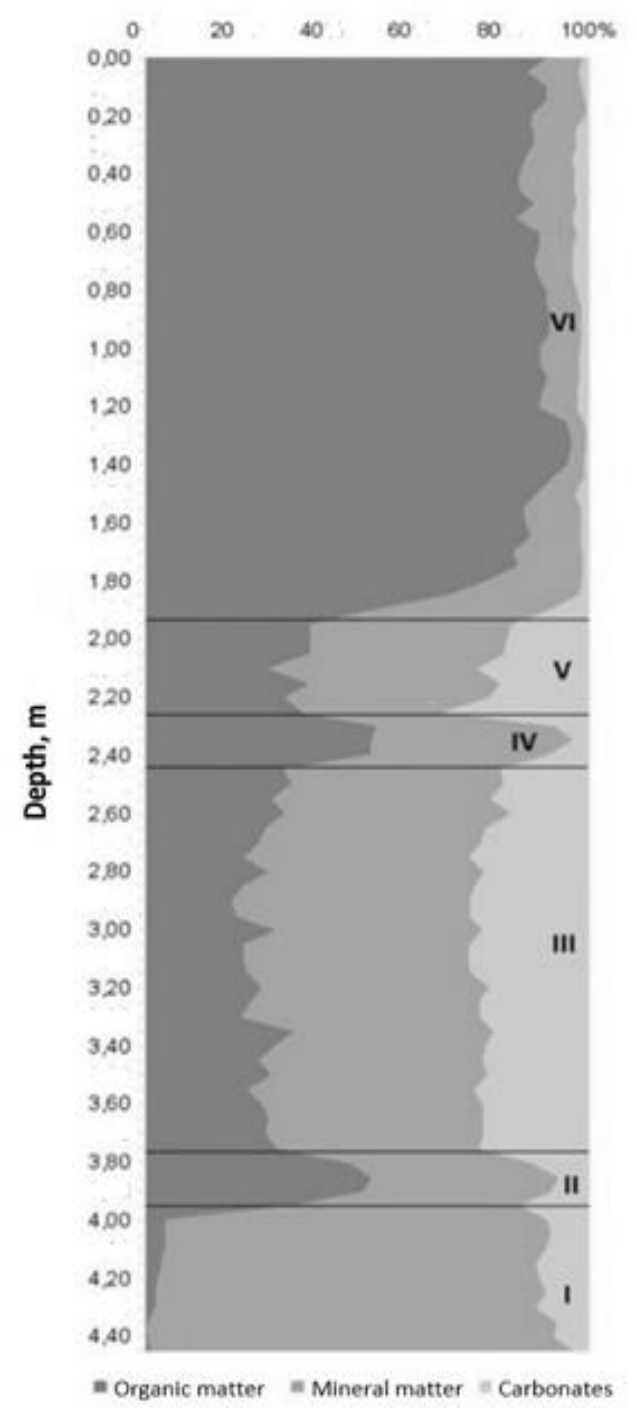

Figure 2. LOI diagram of the Košḳēni

Bay sediments (authors' figure)

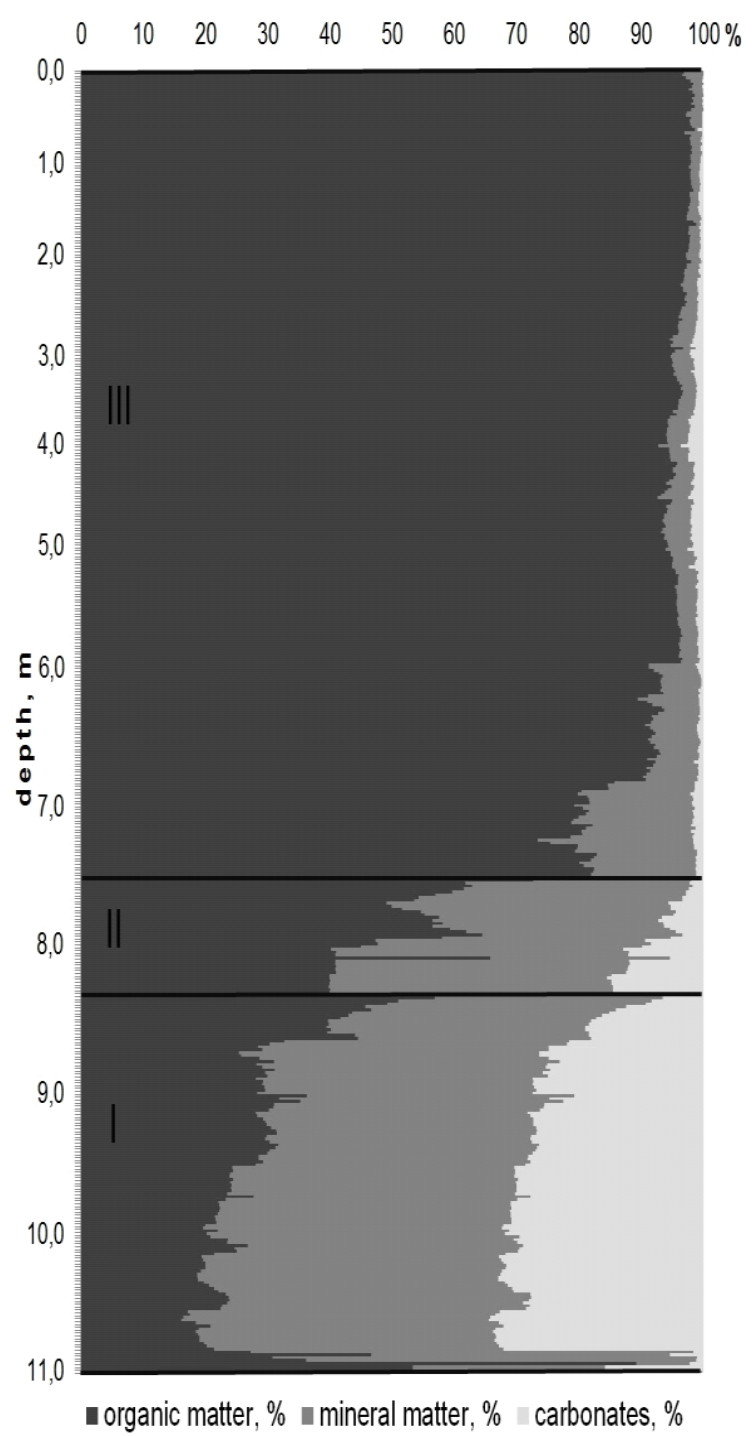

Figure 3. LOI diagram of the Viskūži

Island Mire deposits (authors' figure)

There are three longitudinal embedded depressions in the underwater part of the lake bottom - the deepest is located at the southern part, to the NE from Moricsala and to the $\mathrm{W}$ from Moricsala. Considering that Lake Usma is formed as a glaciodepression (Аболтыньш et al. 1972), the orientation and elevation of Usma Lake is linear and allows us to assume that the asynchronous formation of the individual parts of the lake depression took place during the tongue-type deglaciation stage. Thus, Viskūži Island, along with the peninsulas on the shores of Lake W and E, lies above the end moraine that formed between the active tongue of the glacier in the north and the passive ice in the south. Partial morphological similarity and also the linearity of 
the SW-NE are $1.7 \mathrm{~km}$ long and 0.2-0.7 km wide and are characteristic for Moricsala. There are several stages of erosion of the steep coasts on Moricsala and Viskūži Island. Moricsala is hipsometrically lower, so the height of its steep coasts is not more than 3-5 m, but for Viskūži Island they reach 6-8 m, vertical, unstable bluff parts. Mostly, around Moricsala, as well as around Viskūži Island, there are wide shallow water areas overgrown by reed belts that dampen wave energy (Veinbergs and Jakubovska 1999).

The two largest islands of the lake have differently articulated surface relief characteristics, but there are also flat surfaces and terraces at the same height above the lake level (Veinbergs and Jakubovska 1999), which apparently point to the levels of stabilization during the lake development. Not only the surface of the terrain but also the sediments found in the corings and observation sites indicate the conditions for the formation of the islands. In the 4 boreholes carried out in different places of Viskūži Island, in the highest part (28-32 $\mathrm{m}$ above sea level), there is to be found sand. Under these the changes of glaciolymnic clay and silt layers were recognized as being with a seasonal rhythmic character. Similar glaciolimnic sand, silt and clay have also been found on Moricsala (Veinbergs and Jakubovska 1999). It is only because of the absolute height difference, that the sediment strata in Viskūži Island is $4 \mathrm{~m}$ thicker.

On both islands there are also to be found areas of eolian relief, where dunes and deflation depressions alternate. The formation of eolian relief was possible at the time when the water level was falling and the glaciolimic sand did not cover the vegetation. The prevalence of glaciolimic sediments on both islands of the lake, as well as the erosion bluffs and terraces, are indicative of their initial formation in the same icemelting water basin and can currently be classified as sediment accumulation and erosion remnants under basin conditions. According to the relief profiles made using LIDAR 2016 data for Viskūži Island, there are several notable levels of terraces and flat tops $-30 \mathrm{~m}, 28 \mathrm{~m}, 27 \mathrm{~m}, 23.5-24 \mathrm{~m}$ and $22 \mathrm{~m}$ above sea level. These levels are similar also to those on Moricsala, except for the two highest levels. The accumulation of glaciolimic clays and silt occurred in the Venta-Usma ice-dammed basin, while sand accumulation occurred in the Gulf of Usma in the Baltic Ice Lake (Гринбергс 1957; Страуме 1979; Veinbergs 1990). As the water level dropped, the surface of the islands was flattened and partially eroded. At the elevation mark $25 \mathrm{~m}$ above sea level. E. Grīnbergs (1957) and J. Straume (1979) noted that lake Usma separated from the Baltic ice lake, although later observations do not confirm this (Veinbergs and Jakubovska 1999). According to J. Straume's (1979) observations, the elevation of the terrace surface elevation varies from $24 \mathrm{~m}$ a.s.l. at the southern part of the lake to $26 \mathrm{~m}$ a.s.l. at the northern part, which indicates a different isostatic uplift speed. Changes in palaeo-geographic conditions in the Lake Usma depression in the Holocene are evidenced by the character of organogenic sediments, the samples of which were obtained by coring in mire depressions on Moricsala (Ceriņa et al. 2017), Viskūži Island (Strautnieks et al. 2017) and from the lake bottom in Košķēni Bay 
(Štube et al. 2018 ). Layers of organogenic sediments at all 3 sites have both common and distinct features, including layer thickness.

The maximum thickness of the organogenic sediment is to be found on Viskūži Island, where it reaches $11 \mathrm{~m}$. Organogenic sediments are concentrated in the Viskūži Island mire, which is developed in the S-folded valley with a length of $2.5 \mathrm{~km}$, a width of 150-200 m, and relative height of the slopes being 6-8 m. On the slopes of the downhill, the expressive terraces are clearly visible at certain stages. The elevation of the surface in the lowering is 22-24 $\mathrm{m}$ above sea level, i.e., 1-3 $\mathrm{m}$ above the level of Lake Usma, which means that the partially buried lowering bed is $8 \mathrm{~m}$ below the current lake level. In the Viskūži paludified valley area there were found three different mire types: fen, transitional and raised bog. In core Z1 there has been identified an $8 \mathrm{~m}$ thick peat layer, which covers $3 \mathrm{~m}$ thick sapropel strata (Figure 4 core Z1) shown in the longitudinal section of Viskūži Mire (Figure 4). The absolute age for the peat layer in the valley bottom of deepest core Z1 at the depth $10.93 \mathrm{~cm}$ laying below the sapropel, just above the medium-grained sand, the absolute age AMS ${ }^{14} \mathrm{C}$ is $9080 \pm 50 \mathrm{BP}$ was determined. This peat contains only green moss residues, a small amount of sedge and Bogbean seeds, which are generally characteristic of plant composition in fens. No residues of aquatic animals have been detected.

Seeds and bark fragments of pines have been found in the peat layer and show that the island had been covered with pine forests at this time.

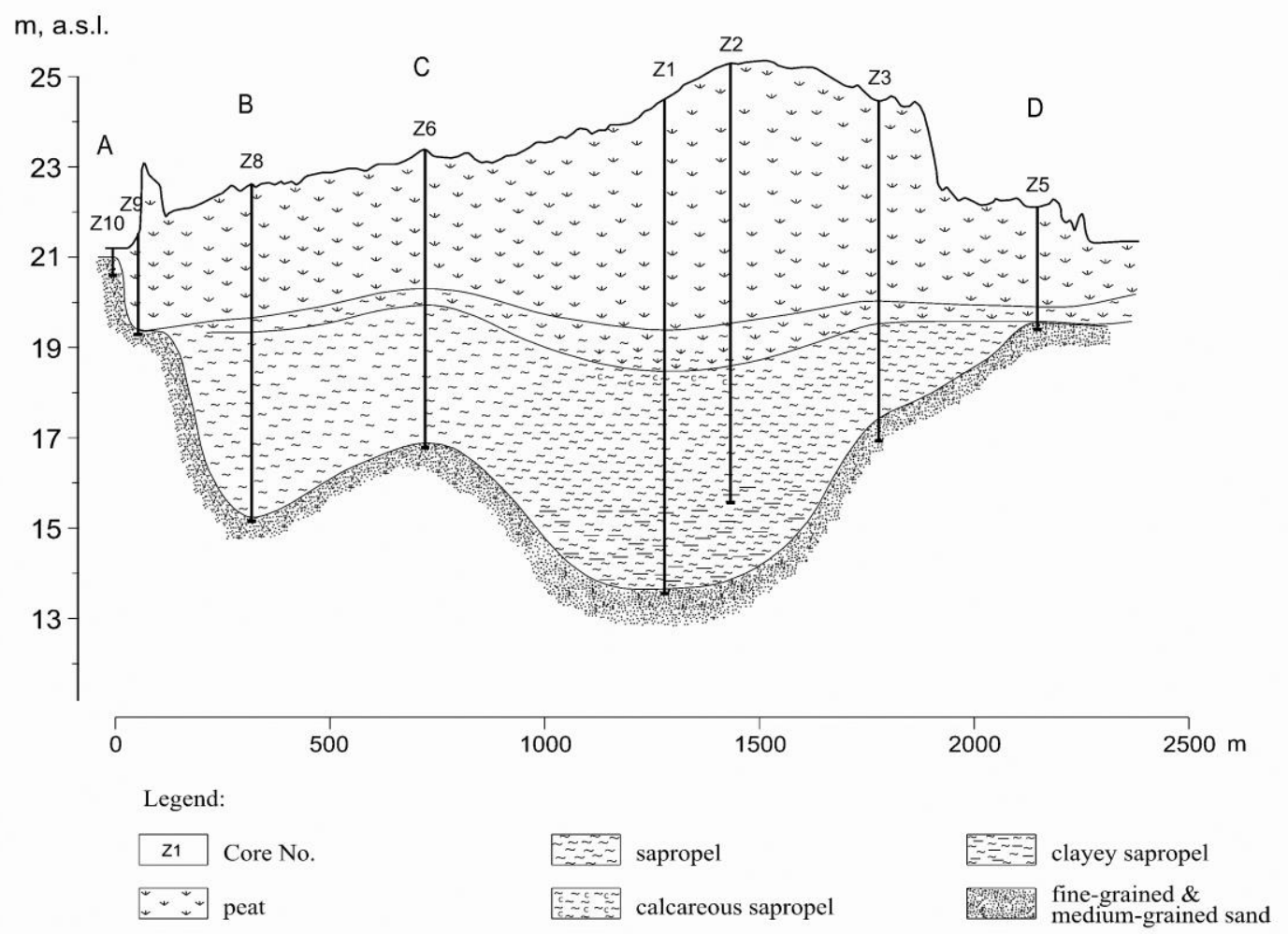

Figure 4. Geological longitudinal section of the S-folded valley crossing Viskūži Island (authors' figure) 
Investigation data reveals that up to the present day the accumulation of sapropel and peat has been undisturbed and steadily rapid - around $1.2 \mathrm{~m}$ per thousand years. On Moricsala, the thickness of the organogenic sediment is only $1.2 \mathrm{~m}$, where the age of the sapropel layer is $9450 \pm 50 \mathrm{BP}$. The thickness of the sediment layer is 10 times smaller, which is likely to be an explanation for the facially different position where the accumulation of sapropel was limited by the action of surface waves, which contributed to erosion of the accumulated material. The rate of accumulation of the peat layer was reduced by decomposition, as the lake and groundwater levels decreased. The relatively rapid accumulation of sapropel and peat has taken place in Košķēni Bay, where the lower $3.3 \mathrm{~m}$ of the stratum have accumulated in about 1000 years, between $6500-5500$ years BP. The top $70 \mathrm{~cm}$ thick layer of peat has developed over 5500 years, which is most likely due to the decomposition of peat with improved aeration.

\section{Conclusion}

The absolute age of the lower part of organogenic sediment layers in all studied sites is similar - over 9000 years. However, the thickness of these is different $-10.9 \mathrm{~m}$, $4.0 \mathrm{~m}$ and $1.2 \mathrm{~m}$, which can be explained by the facial difference. Changes in sediment, plant and aquatic remain composition indicate that sediment accumulation conditions have been changing and they were more different in the Lake Usma basin during the Holocene than at the end of the Late Glacial.

\section{Kopsavilkums}

Usmas ezera ieplaka izveidojusies glaciodepresijā Kursas zemienē, kur uzkrājušies VentasUsmas sprostbaseina un Baltijas ledus ezera nogulumi, kas raksturo paleoǵeogrāfiskos apstākḷus pleistocēna beigās un holocēnā. Detalizētāki ǵeoloğiskie un geomorfolog̣iskie pētījumi ir veikti divās lielākajās Usmas ezera salās - Moricsalā un Viskūžu salā, kā arī Košḳēnu līcī. Salas ir gan ledājkušanas ūdeṇu baseinu nogulumu akumulācijas, gan arī šo ūdeṇu straumju un baseinu viḷnu erozijas rezultāts. Viskūžu salas erozijas stāvkrasti un salu šķērsojošais erozijas padziḷinājums liecina, ka tā ir ledājkušanas ūdeṇu baseina gultnes un straumju erozijas paliksnis. Organogēno nogulumu slāṇkopas apakšějā dạ̣ā nogulumiem noteiktais absolūtais vecums ir līdzīgs, tas pārsniedz 9000 gadu. Taču slāņkopas biezums ir ḷoti atšķirīgs - $11 \mathrm{~m}, 4 \mathrm{~m}$ un 1,2 m. Atšķirīgais nogulumu biezums izskaidrojams ar faciāli atškirī̄go novietojumu. Nogulumu, augu un ūdensdzīvnieku atlieku sastāva pārmaiņas nogulumos liecina, ka Viskūžu salā ir bijis paleoezers, kurā nogulumu uzkrāšanās apstākḷi ir bijuši main̄igi. Pētījumu rezultāti lokālajās vietās ir salīdzināmi, tomēr ir labi novērojamas faciālās atškirīības, kas saistītas ar dažādu nogulumu akumulācijas, erozijas vai sadalī̌sanās ātrumu.

\section{References}

Cerina, A., Kiziks, K., Kalniṇa, L., Nikodemus, O. and Priedniece, E. (2017). Vides un veǵetācijas izmaiņu pazīmes leduslaikmeta beiguposma un holocēna nogulumu griezumā Moricsalas DR dạ̦̄ā. G̦eogrāfija. Geologija. Vides zinātne: referātu tēzes. Latvijas Universitātes 75. zinātniskā konference. Rīga: Latvijas Universitāte, 34-37.

Heiri, O., Lotter, A.F. and Lemcke, G. (2001). Loss on ignition as a method for estimating organic and carbonate content in sediments: reproducibility and comparability of results. Journal of Paleolimnology, 25, 101-110.

Priedniece, E., Ceriņa, A., Kalniņa, L., Nikodemus, O., Kiziks, K. and Lamsters, K. (2016). Holocēna nogulumi Usmas ezera piekrastē pie Košķēniem un Moricsalā. Ģeogrāfija. Ģeoloǵija. Vides 
zinātne: referātu tēzes, Latvijas Universitātes 74. zinātniskā konference. Rīga: Latvijas Universitāte, 362364.

Strautnieks, I., Kalniņa, L., Žagata, S., Sadovina, V., Kiziks, K., Stibe, R., Paparde, L., Lapiņš, D. and Freiberga, G. (2017). Viskūžu salas reljefs un ǵeologiskās uzbūves īpatnības. Ģeogrāfija. Ģeologija. Vides zinātne : referātu tēzes. Latvijas Universitātes 75. zinātniskā konference. Rīga: Latvijas Universitāte, 175-177.

Štube, A., Kalniņa, L. and Ceriņa, A. (2018). Liecības par paleoǵeogrāfiskām izmaiņām Usmas ezera Z līcī pie Košḳēniem. Geogrāfija. Geologija. Vides zinātne : referātu tēzes: Latvijas Universitātes 76. zinātniskā konference. Rīga: Latvijas Universitāte, 108-109.

The Latvian Geospatial Information Agency Map. https://kartes.lgia.gov.lv/karte/ (11.02.2019).

Veinbergs, I. (1999). Baltijas jūras leduslaikmeta beiguposma un pēcleduslaikmeta baseinu Latvijas krasta zonas morfo- un litodinamika (pēc Latvijas piekrastes pētījumu rezultātiem). Latvijas Universitātes G̦eologijas institūts, atskaite.

Veinbergs I. and Jakubovska I. (1999). Moricsala Island and Usma Lake: development of natural environment during the Late Glacial time and Holocene (in Latvian). Folia Geographica, 7, 58-72.

Аболтыньш О.П., Вейнбергс И.Г., Стелле В.Я., Эберхард Г.Я. (1972). Основные комплексы маргинальных образований и отступание ледника на территории Латвийской ССР. В кн.: Горецкий Г.И., Погуляев Д.И., Шик С. М. (ред.) Краевые образования материковых оледенений. Москва: Наука, 30-37.

Вейнбергс, И. (1975). Формирование Абавско-Слоценской системы долины талых ледниковых вод. Вопросы четветичных отложений Латвии, 8. Рига: Зинатне, 82-101.

Гринбергс Э.Ф. (1957). Позднеледниковая и послеледниковая история побережья Латвийской ССР. Рига, 122.

Страуме Я.А. (1979). Геоморфология. Мисанс Я.П., Брангулис А,П., Даниланс И.Я., Куршс В.М. (ред.) Геологическое строение и полезные ископаемые Латвии, Рига: Зинатне, $297-$ 439.

\title{
EVIDENCE OF PALAEO-CLIMATE CHANGES AND THEIR IMPACT ON SEDIMENT ACCUMULATION CONDITIONS IN THE LUBĀNS STONE-AGE SETTLEMENT AREAS
}

\section{Liecības par paleoklimata pārmaiṇām un to ietekmi uz nogulumu uzkrāšanās apstākḷiem Lubāna akmens laikmeta apmetṇu teritorijās}

\author{
Liga Paparde ${ }^{1}$, Laimdota Kalniña ${ }^{1}$, Aija Ceriña ${ }^{1}$, Ilze Loze², \\ Ivars Strautnieks ${ }^{1}$, Jānis Dreimanis ${ }^{1}$ \\ ${ }^{1}$ University of Latvia, Faculty of Geography and Earth Sciences \\ ${ }^{2}$ University of Latvia, Institute of Latvian History \\ liga.paparde@gmail.com
}

\begin{abstract}
Changes in palaeo-climate and palaeo-geographic conditions have influenced palaeo-vegetation and sediment accumulation conditions during the development of Lake Lubāns. These circumstances have also affected human life conditions and the distribution of Stone-Age settlement sites. To discover notions about evidence of sediment accumulation condition changes and reconstruct the palaeo-geographic
\end{abstract}

